\title{
Efficacy of vermicompost and/or plant growth promoting bacteria on the plant growth and development in gladiolus
}

\author{
Fazilet Parlakova Karagöz ${ }^{1 *}$, Atilla Dursun ${ }^{1}$, Nasibe Tekiner ${ }^{2}$, Raziye Kul ${ }^{1}$, Recep Kotan ${ }^{2,3}$
}

\begin{abstract}
The use of environmental and sustainable ornamental flower production practices with renewable resources has drawn worldwide interest. One of these renewable resources is vermicompost (earthworm castings). In recent years, increasing demand for improving environmental quality have focused on the importance of Plant Growth Promotion Bacteria (PGPBs) in agriculture. Vermicomposts also help microbial agents function effectively in soil. In this study, a total of six treatments [A: PGPB formulation, B: Not autoclaved vermicompost, C: Autoclaved vermicompost, D: Not autoclaved vermicompost+PGPBs, E: Autoclaved vermicompost+PGPBs, F: Control (untreated bacteria and vermicompost)] were tested for their effects on the plant growth and development parameters in gladiolus (Gladiolus grandiflorus L. 'Red Beauty') in greenhouse condition. Vermicompost was added to the related pots by dissolving in water. After the addition of vermicompost, PGPB formulation was given immediately to related pots. All the treatments were applied to soil once in three leaf stage, close to the plant root zone. Parameters in terms of yield and quality attributes of plant and corm were determined and analyzed. The treatment A increased in plant height of gladiolus of $24.55 \%$ rate. The earliest times to flowering was determined in E application (100.48 day), which also increased in corm diameter with rate of $17.41 \%$ and number of corms and cormels with rate of $151.83 \%$ according to F application. Results indicated that the treatment E promoted overall better performance as compared to other treatments diameter of flowers for number of leaves per plant, number of florets per spike, stem diameter, spike length, fresh and dry weight of flowers, the number and diameter of corm. Autoclaved vermicompost can be good choice in gladiolus cultivation but it should be enriched with PGPB.
\end{abstract}

Keywords: autoclaved, flower development, Gladiolus grandiflorus L. PGPR, PGPB, vermicomposting

\section{Introduction}

Gladiolus (sword lily) is known as queen of bulbous flower due to their elegant attractive spikes of different hues, varying sizes and long vase life (Jabbar et al., 2018). Gladiolus grandiflorus L. is an important cut flower belongs to Iridaceae family. Gladiolus occupies fourth place in the international trade after rose, carnation and chrysanthemum, in the cut flower industry (Tirkey et al., 2017).

Usage of potting medium has a crucial influence in improving the growth quality of ornamental plants. The quality and yield of potted flower can be improved by adding organic materials to the medium to enrich the physical properties of the potting medium and to ensure the continuity of the growing medium. One of these organic materials is vermicompost. Vermicomposts, specifically earthworm casts, are the final product of vermicomposting (Bawa et al., 2016). The vermicompost can amendment and improve fertility of potting media (Yang et al., 2015) due to uniform and odorless material, containing good physical structure, mineral and trace elements, plant growth regulating substances or hormones (Bachman and Metzger, 2008), promoting biological activity (Arancon et al., 2004). Using of vermicompost increased due to impacts of earthworms on ecosystem functioning, the sustainable management of agroecosystems and rehabilitation of damaged and contaminated lands. Vermicomposts were reported to be an appropriate substrate for growing marigolds (Hidalgo et al., 2006; Shweta Singh, 2007; Shadanpour et al., 2011), China aster (Nethra et al., 1999; Balaji et al., 2006), gladiolus cut flower (Gangadharan and Gopinath, 2000), gerbera (Narayanagowda, 2003), dahlia (Warade et al., 2007), busy Lizzy (Asciutto et al., 2006), cornflower (Bachman and Metzger, 2008) and chrysanthemum (Hidalgo and Harkess, 2002).

One of other organic materials added in the growing medium is also PGPB. There are beneficial effects of PGPB (plant growth-promoting bacteria) which, result in stimulation of host growth, when grown in association with a host plant. Therefore, nitrogen fixing and phosphate

\footnotetext{
${ }^{1}$ Atatürk University, Department of Horticulture, Agriculture Faculty, Erzurum, Turkey; *Corresponding author: f.parlakova@atauni.edu.tr

${ }^{2}$ Atatürk University, Department of Horticulture, Agriculture Faculty, Erzurum, Turkey;

${ }^{3}$ Supersol Organic Agriculture and Livestock, Fertilizer, Agrochemical Industry and Trade Limited Company, İzmir, Turkey
} 
solubilizing bacteria, including Bacillus sp., Azotobacter sp., Azospirillum sp., Beijernckia sp., Pseudomonas sp. are generally used in environmental friendly plant growing and also potting media. The use of PGPB in agriculture of ornamental plants (Zulueta-Rodriguez et al., 2014, Arab et al., 2015, Parlakova Karagöz et al., 2016) is increasing day by day. A lot of studies were evaluated in order to determine of combined effect of biofertilizers and vermicompost in ornamental plants Tagetes patula (French marigold) (Karuppaiah, 2005), Tagetes erecta L. (African marigold) (Nazari et al., 2008), gerbera (Narayanagowda, 2003) Dahlia variabilis L. (dahlia) (Pandey et al., 2017).

Singh et al. (2011) indicated that there is mutualistic relationship among microorganisms and earthworms in organic waste degradation. In other words, vermicompost is the combination of the earthworms and the microorganisms (Singh et al., 2011). Microorganism found in the intestine and gut of earthworms get its nourishment from organic material and decompose it into finer particles (Edwards and Bohlen, 1996). Vermicompost is in rich microbial agents and diversity, specifically bacteria, fungi and actinomycetes (Arancon et al., 2004). Vermicomposts also contain the pathogens due to the vermicomposting process temperature $\left(35^{\circ} \mathrm{C}\right.$ - Ali et al., 2015) is not high enough for pathogen kill (Ndegwa and Thompson, 2001). Ndegwa and Thompson (2001) considered that there can be two possibilities that are generally proposed to achieve better output by using vermicomposts: prevermicomposting followed by composting or precomposting followed by vermicomposting. The number of studies on this subject is limited. Gajalakshmi et al. (2002) obtained that growth of water hyacinth was increased by using the precomposting followed by vermicomposting.

This study was carried out in order to compare the applications and to determine effects on the plant growth and development parameters in gladiolus (Gladiolus grandiflorus L. "Red Beauty") of PGPB formulation including Bacillus subtilis RK-1977, Bacillus megaterium RK-1978 and Pseudomonas fluorescens RK-1979 strains, non-autoclaved vermicompost, autoclaved vermicompost and combinations with each other in pot.

\section{Materials and Methods}

Corms of Gladiolus grandiflorus L. "Red Beauty" used in the experiments were purchased from Asya Lale Company in Turkey (Konya). The average size of these corms was $2.0-2.5 \mathrm{~cm}$ in circumference. The study was conducted under the natural light of unheated greenhouse condition at the Department of Horticulture of Agricultural Faculty, Atatürk University in the period of the AprilAugust, 2017. Six treatments (Table 1) were applied in a completely randomized block design with 4 replicates.

Table 1. Treatments used in the study and their codes

\begin{tabular}{|c|c|}
\hline Code of treatments & Treatments details \\
\hline A & $\begin{array}{l}\text { PGPB formulation (Bacillus subtilis RK-1977 + Bacillus megaterium } \\
\text { RK-1978 + Pseudomonas fluorescens RK-1979) }\end{array}$ \\
\hline B & Not autoclaved vermicompost $\left(60 \mathrm{~kg} \mathrm{da}^{-1}\right)$ \\
\hline $\mathrm{C}$ & Autoclaved vermicompost $\left(60 \mathrm{~kg} \mathrm{da}^{-1}\right)$ \\
\hline $\mathrm{D}$ & Not autoclaved vermicompost $\left(60 \mathrm{~kg} \mathrm{da}^{-1}\right)+$ PGPB formulation \\
\hline E & Autoclaved vermicompost $\left(60 \mathrm{~kg} \mathrm{da}^{-1}\right)+$ PGPB formulation \\
\hline $\mathrm{F}$ & Control (untreated bacteria and vermicompost) \\
\hline
\end{tabular}

The content of vermicompost used in the study is as follows: Organic matter 40-50\%; total nitrogen (N) $2.3 \%$; total phosphorus $\mathrm{P}_{2} \mathrm{O}_{5} 1.1 \%$; water soluble potassium $\mathrm{K}_{2} \mathrm{O}$ $1.1 \%$. Red Californian Worms (Lumbricus rubellis and Eisenia foetida) were used in order to reproduce organic fertilizer. Amount of vermicompost used in the study is 60 $\mathrm{kg} \mathrm{da}^{-1}$ for $50 \mathrm{~L}$ (Riverm, 2018). Vermicompost used in the experiments were purchased from The Riverm Company in Turkey (İstanbul). PGPB formulation was created with Bacillus subtilis RK-1977, Bacillus megaterium RK-1978 and Pseudomonas fluorescens RK-1979 strains (Table 2) and stored at $+4{ }^{\circ} \mathrm{C}$ temperature prior to use. The bacterial strains were obtained from the culture collection unit of Atatürk University, Faculty of Agriculture, the Department of Plant Protection, Turkey. In this formulation, density of each strain was $10^{8} \mathrm{cfu} \mathrm{ml}^{-1}$. 
Table 2. Bacterial isolates used in the study and some biochemical properties (Kotan et al., 2005)

\begin{tabular}{|c|c|c|c|c|c|c|c|}
\hline Isolate No & Bacterial species & SIM & $\begin{array}{c}\text { Location } \\
\text { ( in Turkey })\end{array}$ & Host & Nitrogen & Phosphate & Siderophore \\
\hline RK-1977 & Bacillus subtilis & 0.637 & Erzurum & Grass & + & + \\
\hline RK-1978 & Bacillus megaterium & 0.785 & Erzurum & Grass & + & + & + \\
\hline RK-1979 & $\begin{array}{c}\text { Pseudomonas fluo- } \\
\text { rescens }\end{array}$ & 0.764 & Erzurum & Grass & + & + \\
\hline
\end{tabular}

SIM: Similarity index, +: Positive, -: Negative)

Corms were planted $15 \mathrm{~cm}$ intervals and $7-8 \mathrm{~cm}$ depth in pots (56-liter volume, used flower pot sizes are $34 \times 82 \times 29 \mathrm{~cm}$ ) during the third week of April in 2017. All the treatments were applied one times to soil at three leaf stage. Sixteen corms were planted in each treatment in pots. $128 \mathrm{~g}$ of autoclaved vermicompost was dissolved in 1600 $\mathrm{mL}$ of water and $128 \mathrm{~g}$ not autoclaved vermicompost was dissolved in $1600 \mathrm{~mL}$ of water. So as to be $200 \mathrm{~mL}$ per pot of vermicompost solution was added to related pots. After the addition of vermicompost, PGPB formulation was given immediately to related pots. Bacterial suspension $(150 \mathrm{~mL}$ pot $^{-1}$ ) was applied one times to soil at three leaf stage. All the treatments were applied to soil once in three leaf stage, close to the plant root zone. Treatments were arranged in a greenhouse with natural light at a temperature 25-34 ${ }^{\circ} \mathrm{C}$ during the day and $16-20{ }^{\circ} \mathrm{C}$ at night. 10 randomly plants per treatment were selected and main stem diameter of plant, plant height, length and breadth of leaf, number of leaves per plant, times to flowering, and yield attributes included color of leaf and flower, number of florets per spike, spike length, stalk length, stalk diameter, fresh and dry weight of flowers were determined in (by methods of
Cruz et al., 2018) 4 months after planting. Corm quality in terms of corm diameter and length, number of contractile root per corm, number of corm and cormel and fresh and dry weight of corms (by methods of Seng et al. 2016) were recorded at harvest stage.

All data were subjected by analysis of variance, which was performed using the SPSS version 20.0 statistical software package (SPSS Inc., Chicago, IL, USA) and means were separated by Duncan's multiple range tests. The significance of treatment effects is presented as: ns, not significant (at $p>0.05$ ); ${ }^{*}, p<0.05 ; * *, p<0.01 ; * * *, p<0.001$.

\section{Results}

\section{Plant and flower quality characteristics}

Main stem diameter of plant $(\mathrm{mm})$ : The results regarding the main stem diameter of the plants showed the significant difference between the applications. Main stem diameter with $11.83 \mathrm{~mm}$ in E application was numerically higher than $\mathrm{F}$ application with the diameter of $9.78 \mathrm{~mm}$. In addition, the $\mathrm{B}$ and $\mathrm{D}$ applications with $\mathrm{E}$ application were included in the same statistical group (Table 3).

Table 3. Comparison of vegetative characters and flowering day in different treatments

\begin{tabular}{|c|c|c|c|c|}
\hline Treatments & $\begin{array}{c}\text { Main stem diameter } \\
\text { of plant }(\mathbf{m m})\end{array}$ & Plant height $\mathbf{( c m )}$ & $\begin{array}{c}\text { Number of leaves } \\
\text { (number/plant) }\end{array}$ & Leaf length (cm) \\
\hline A & $10.90 \pm 0.56 \mathrm{ab}^{*}$ & $75.50 \pm 1.44 \mathrm{a}^{* * *}$ & $7.69 \pm 0.58 \mathrm{bc}^{* *}$ & $35.04 \pm 2.83 \mathrm{bc}^{*}$ \\
\hline $\mathrm{B}$ & $11.75 \pm 0.92 \mathrm{a}$ & $63.38 \pm 1.82 \mathrm{c}$ & $6.71 \pm 0.31 \mathrm{~b}$ & $39.63 \pm 3.87 \mathrm{a}$ \\
\hline $\mathrm{C}$ & $10.58 \pm 1.17 \mathrm{ab}$ & $69.57 \pm 5.93 \mathrm{~b}$ & $8.19 \pm 0.46 \mathrm{a}$ & $38.97 \pm 1.92 \mathrm{ab}$ \\
\hline $\mathrm{D}$ & $11.15 \pm 1.07 \mathrm{a}$ & $70.34 \pm 3.91 \mathrm{~b}$ & $8.00 \pm 0.77 \mathrm{ab}$ & $32.70 \pm 2.60 \mathrm{c}$ \\
\hline $\mathrm{E}$ & $11.83 \pm 0.54 \mathrm{a}$ & $65.08 \pm 2.85 \mathrm{bc}$ & $7.69 \pm 0.63 \mathrm{ab}$ & $35.35 \pm 2.22 \mathrm{bc}$ \\
\hline F & $9.78 \pm 0.28 \mathrm{~b}$ & $60.62 \pm 2.39 \mathrm{c}$ & $6.44 \pm 0.97 \mathrm{c}$ & $38.54 \pm 2.01 \mathrm{ab}$ \\
\hline Mean & $11.00 \pm 1.02$ & $67.41 \pm 5.88$ & $7.45 \pm 0.88$ & $36.70 \pm 3.48$ \\
\hline
\end{tabular}

ns, not significant (at $p>0.05$ );,$p<0.05 ; * *, p<0.01 ; * * *, p<0.001$. 
Plant height $(\mathrm{cm})$ : The applications had significant (at $p<0.001$ ) effects on the plant height $(\mathrm{cm})$ and the highest plant height was obtained from the A application $(75.50 \mathrm{~cm})$. The A application increased in plant height of gladiolus of $24.55 \%$ rate, according to $F$ application (60.62 $\mathrm{cm}$ ) (Table 3).

Number of leaves (number/plant): Number of leaves was significant (at $p<0.01)$ according to the $\mathrm{F}$ application. Moreover, $\mathrm{C}$ application produced the highest number of leaves 8.19 number/plant, while the number of leaves was 6.44 number/plant in the case of control application (Table 3).

Leaf colorimetric values: The effects of all applications on the leaf colorimetric values of ( $\mathrm{L}^{*}$ and $\mathrm{b}^{*}$ ) gladiolus plants were not significant (at $p>0.05$ ) according to the control application. $\mathrm{a}^{*}\left(+\mathrm{a}^{*}\right.$ red direction; $-\mathrm{a}^{*}$ green direction) was significant (at $p<0.01$ ) according to the control application. Mean colour space value $a^{*}$ was $(+)$ 45.11 (Fig. 1). The highest mean colour space value, $a^{*}$ was determined in E application.
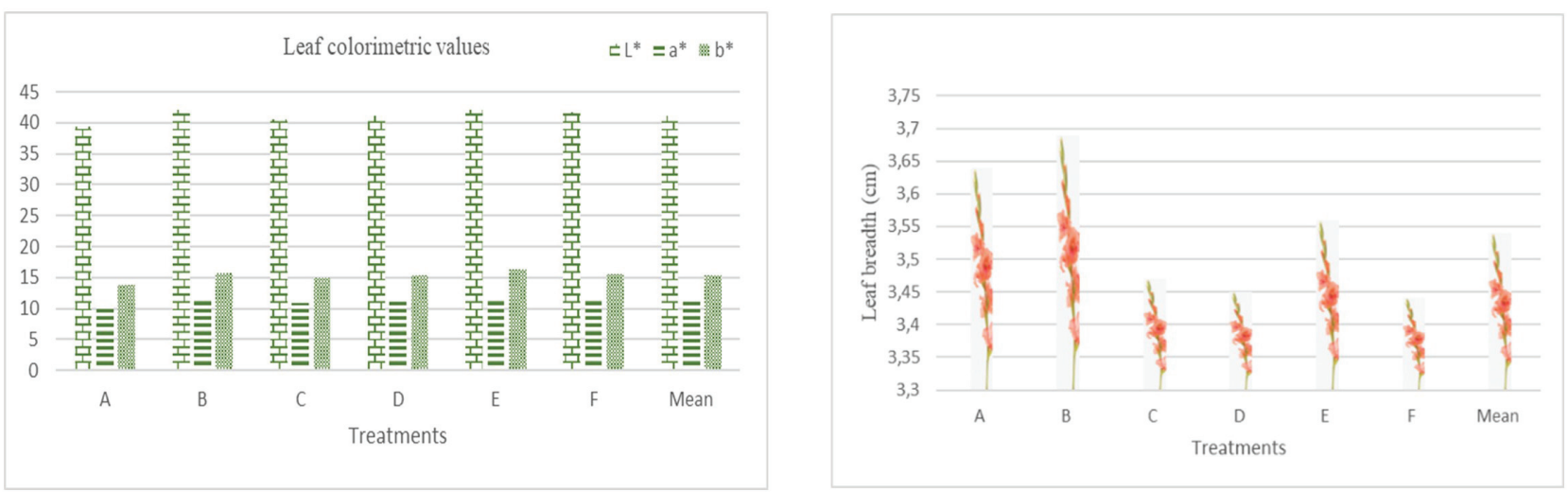

Figure 1. Comparison of leaf colorimetric values and leaf breadth $(\mathrm{cm})$ in different treatments

Leaf length $(\mathrm{cm})$ : Length of leaves was significant (at $p<0.05)$ according to the $\mathrm{F}$ application. The longest leaf length was obtained from the B application $(39.63 \mathrm{~cm})$ but the $\mathrm{C}$ and $\mathrm{F}$ applications with $\mathrm{B}$ application were included in the same statistical group (Table 3).

Leaf breadth $(\mathrm{cm})$ : Though leaf breadth did not show significant variations among the applications, the broadest leaf $(3.69 \mathrm{~cm})$ was produced in $\mathrm{B}$ application and the narrowest leaf $(3.44 \mathrm{~cm})$ was recorded in $\mathrm{F}$ application ( Fig. 1).

Times to flowering (day): The applications had significant (at $p<0.001$ ) effects on the times to flowering (day), and the mean times to flowering was 104.24 day. The latest times to flowering was obtained from $\mathrm{F}$ application while the earliest times to flowering was determined in $\mathrm{E}$ application (100.48 day) (Table 4).

Table 4. Comparison of floral characters in different treatments

\begin{tabular}{|c|c|c|c|c|c|c|c|}
\hline \multirow{2}{*}{ Treatments } & \multirow{2}{*}{$\begin{array}{l}\text { Days to } \\
\text { flowering }\end{array}$} & \multirow{2}{*}{$\begin{array}{c}\text { Number of } \\
\text { Florets per } \\
\text { spike }\end{array}$} & \multicolumn{3}{|c|}{ Flower } & \multirow{2}{*}{$\begin{array}{l}\text { Spike lenght } \\
\text { (cm) }\end{array}$} & \multirow{2}{*}{$\begin{array}{c}\text { Stalk length } \\
\text { (cm) }\end{array}$} \\
\hline & & & $\mathbf{L} *(+)$ & $a^{*}(+)$ & $b^{*}(+)$ & & \\
\hline A & $102.25 \pm 1.50 \mathrm{bc}^{* * *}$ & $8.06 \pm 0.82 \mathrm{a}^{* * *}$ & $30.86 \pm 5.72 \mathrm{c}^{* * *}$ & $39.93 \pm 4.28 \mathrm{~b}^{* * *}$ & $17.90 \pm 3.40 \mathrm{c}^{* *}$ & $26.45 \pm 1.11 \mathrm{a}^{* *}$ & $42.56 \pm 1.50 \mathrm{~d}^{* * *}$ \\
\hline B & $103.31 \pm 2.36 \mathrm{bc}$ & $9.23 \pm 1.03 \mathrm{a}$ & $42.51 \pm 3.63 \mathrm{ab}$ & $46.84 \pm 0.77 \mathrm{a}$ & $23.72 \pm 0.66 \mathrm{a}$ & $29.23 \pm 3.20 \mathrm{a}$ & $51.53 \pm 3.17 \mathrm{c}$ \\
\hline $\mathrm{C}$ & $102.81 \pm 1.68 \mathrm{bc}$ & $8.96 \pm 1.34 \mathrm{a}$ & $38.51 \pm 1.46 \mathrm{~b}$ & $40.69 \pm 1.97 \mathrm{~b}$ & $19.95 \pm 0.87 \mathrm{bc}$ & $29.55 \pm 1.16 \mathrm{a}$ & $51.87 \pm 3.50 \mathrm{c}$ \\
\hline $\mathrm{D}$ & $105.86 \pm 1.36 \mathrm{~b}$ & $8.75 \pm 1.08 \mathrm{a}$ & $39.91 \pm 2.74 \mathrm{ab}$ & $46.07 \pm 1.34 \mathrm{a}$ & $22.02 \pm 1.54 \mathrm{ab}$ & $28.64 \pm 4.26 \mathrm{a}$ & $55.89 \pm 2.10 \mathrm{bc}$ \\
\hline $\mathrm{E}$ & $100.48 \pm 4.57 \mathrm{c}$ & $6.25 \pm 0.20 \mathrm{~b}$ & $44.40 \pm 1.61 \mathrm{a}$ & $48.01 \pm 1.84 \mathrm{a}$ & $23.80 \pm 0.95 \mathrm{a}$ & $28.88 \pm 1.35 \mathrm{a}$ & $60.70 \pm 3.46 \mathrm{a}$ \\
\hline $\mathrm{F}$ & $110.74 \pm 0.55 \mathrm{a}$ & $4.46 \pm 0.42 \mathrm{c}$ & $40.07 \pm 1.72 \mathrm{ab}$ & $49.14 \pm 0.98$ a & $22.18 \pm 2.34 \mathrm{ab}$ & $20.53 \pm 2.27 b$ & $57.10 \pm 2.59 \mathrm{ab}$ \\
\hline Mean & $104.24 \pm 3.98$ & $7.62 \pm 1.93$ & $39.38 \pm 5.19$ & $45.11 \pm 4.10$ & $21.59 \pm 2.71$ & $27.21 \pm 3.91$ & $53.27 \pm 6.36$ \\
\hline
\end{tabular}


Number of florets per spike: The number of florets per spike was significantly higher in A, B, C and D applications than that of these in $\mathrm{F}$ and $\mathrm{E}$ application $(p<0.001)$. The maximum number of florets per spike was obtained from the B application (9.23) and C application (8.96) (Table 4). $\mathrm{B}$ application was increased in number of florets per spike with rate of $106.95 \%$ according to $\mathrm{F}$ application.

Flower colorimetric values: Flower colorimetric values ( $\left.\mathrm{L}^{*}, \mathrm{a}^{*}, \mathrm{~b}^{*}\right)$ was influenced by PGPB and vermicompost applications. The $\mathrm{L}^{*}(p<0.001)$ and $\mathrm{b}^{*}$ $(p<0.01)$ values were more significant in E application than that of in $\mathrm{F}$ application. The highest mean value for the flower $\mathrm{L}^{*}$ value was determined in E application with 44.40. All $\mathrm{a}^{*}$ values taken from the flowers are positive $(+)$. The darkest red flower color was determined in $\mathrm{F}$ application where the highest $\mathrm{a}^{*}$ value was obtained (Table 4). F with all applications except for $\mathrm{A}$ application were included in the same statistical group. All $b^{*}$ values obtained in this study were measured as positive numbers. The values of the $b^{*}$ parameter represent yellow color. Accordingly, the lowest $b^{*}$ value was determined in A application.

Spike length $(\mathrm{cm})$ : Spike length ranged from $20.53 \mathrm{~cm}$ in $\mathrm{F}$ application to $29.55 \mathrm{~cm}$ in $\mathrm{C}$ application and $29.23 \mathrm{~cm}$ in B application, $28.88 \mathrm{~cm}$ in E application, respectively (Table 4).

Stalk length $(\mathrm{cm})$ : There is a significant increase in stalk length $(p<0.001)$ among the treatments and the $\mathrm{E}$ application resulted an increase in stalk length by 60.70 (rate of $6.30 \%$ ) $\mathrm{cm}$ as compared to control (Table 4).

Stalk diameter $(\mathrm{mm})$ : The data pertaining to stalk diameter and statistical analysis also reveals that, Table 4, there was nonsignificant difference between applications (Fig. 2).
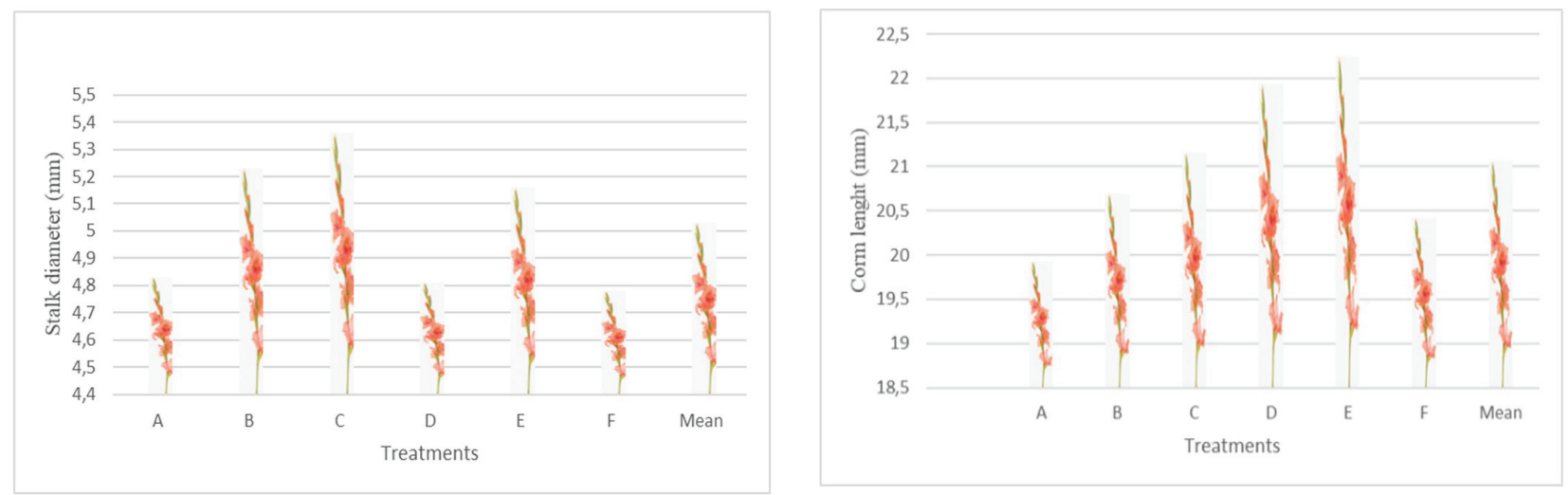

Figure 2. Comparison of stalk diameter and corm length $(\mathrm{mm})$ in different treatments

Fresh weight offlower branch (g): As can be seen in Table 3 , there was a significant difference (at $p<0.001$ ) between the applications regarding the fresh weight of flower branch so that $\mathrm{D}$ application showed higher fresh weight of flower branch (34.36 g). The lower fresh weight of flower branch (12.77 g) was recorded in A application (Table 5, Fig. 3).
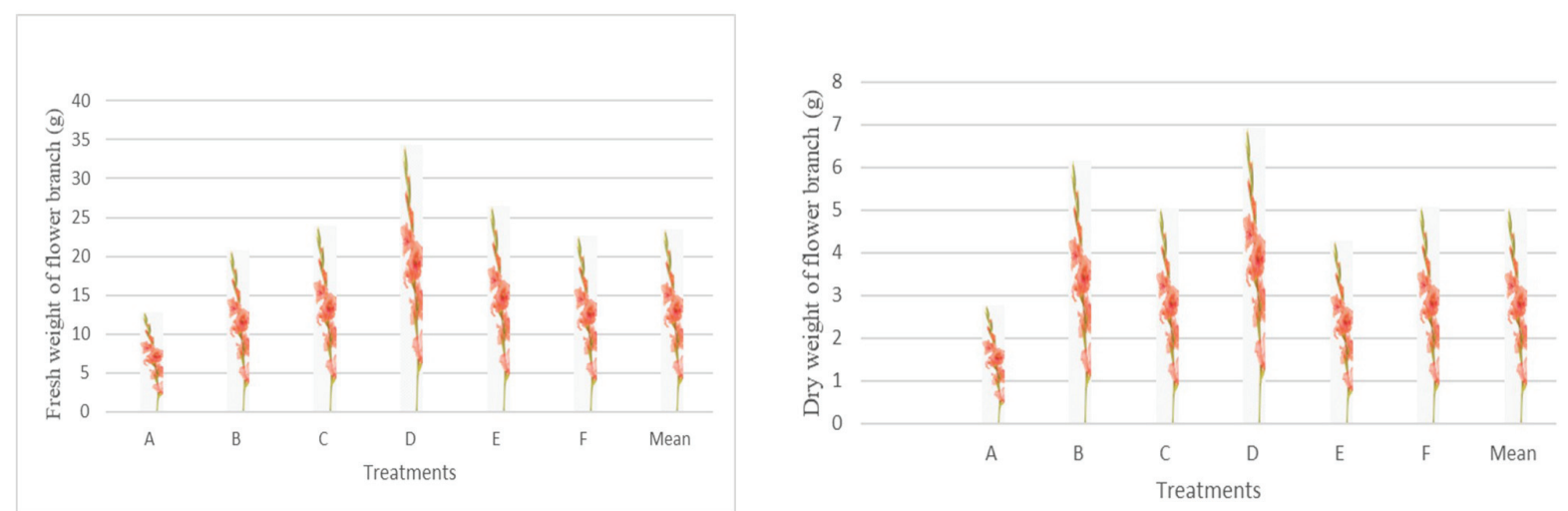

Figure 3. Comparison of fresh and dry weight of flower branch $(\mathrm{g})$ in different treatments 
Table 5. Comparison of fresh and dry weight of flower branch and corm characters in different treatments

\begin{tabular}{|c|c|c|c|c|c|c|c|}
\hline Treatments & $\begin{array}{l}\text { Fresh weight of } \\
\text { flower branch } \\
\text { (g) }\end{array}$ & $\begin{array}{l}\text { Dry weight of } \\
\text { flower branch } \\
\text { (g) }\end{array}$ & $\begin{array}{c}\text { Corm diameter } \\
(\mathrm{mm})\end{array}$ & $\begin{array}{l}\text { Number of } \\
\text { contractile } \\
\text { root per corm }\end{array}$ & $\begin{array}{c}\text { Number of } \\
\text { Corm and } \\
\text { Cormel }\end{array}$ & $\begin{array}{l}\text { Corm fresh } \\
\text { weight (g) }\end{array}$ & $\begin{array}{l}\text { Corm dry } \\
\text { weight (g) }\end{array}$ \\
\hline A & $12.77 \pm 1.90 \mathrm{e}^{* * *}$ & $2.77 \pm 0.68 \mathrm{c}^{* * *}$ & $33.53 \pm 0.96 \mathrm{bc}^{* * *}$ & $8.02 \pm 1.57 b c^{* * *}$ & $2.50 \pm 1.17 \mathrm{~b}^{* *}$ & $12.59 \pm 0.54 \mathrm{~cd}^{* * *}$ & $2.03 \pm 0.81 \mathrm{~b}^{*}$ \\
\hline B & $20.78 \pm 1.79 \mathrm{~d}$ & $6.15 \pm 0.47 \mathrm{a}$ & $35.76 \pm 1.62 \mathrm{ab}$ & $7.75 \pm 1.26 \mathrm{bc}$ & $2.00 \pm 1.08 \mathrm{~b}$ & $17.21 \pm 0.95 \mathrm{a}$ & $4.87 \pm 1.53 \mathrm{a}$ \\
\hline $\mathrm{C}$ & $23.94 \pm 0.62 \mathrm{c}$ & $5.04 \pm 0.73 \mathrm{~b}$ & $29.41 \pm 2.43 \mathrm{~d}$ & $8.36 \pm 0.65 \mathrm{~b}$ & $1.56 \pm 0.83 \mathrm{~b}$ & $17.66 \pm .66 \mathrm{a}$ & $4.30 \pm 1.28 \mathrm{a}$ \\
\hline D & $34.36 \pm 1.66 \mathrm{a}$ & $6.94 \pm 0.58 \mathrm{a}$ & $35.35 \pm 0.52 \mathrm{ab}$ & $11.29 \pm 0.58 \mathrm{a}$ & $1.75 \pm 0.79 \mathrm{~b}$ & $14.44 \pm 1.66 \mathrm{bc}$ & $2.23 \pm 0.46 \mathrm{~b}$ \\
\hline $\mathrm{E}$ & $26.56 \pm 1.70 \mathrm{~b}$ & $4.29 \pm 0.40 \mathrm{~b}$ & $36.88 \pm 0.90 \mathrm{a}$ & $8.86 \pm 0.85 \mathrm{~b}$ & $4.13 \pm 1.16 \mathrm{a}$ & $15.01 \pm 1.88 \mathrm{~b}$ & $2.16 \pm 0.90 \mathrm{~b}$ \\
\hline $\mathrm{F}$ & $22.70 \pm 1.18 \mathrm{~cd}$ & $5.08 \pm 0.52 \mathrm{~b}$ & $31.41 \pm 1.76 \mathrm{~cd}$ & $6.75 \pm 0.53 \mathrm{c}$ & $1.64 \pm 0.44 \mathrm{~b}$ & $11.84 \pm 1.42 \mathrm{~d}$ & $2.12 \pm 0.54 \mathrm{~b}$ \\
\hline Mean & $23.52 \pm 6.74$ & $5.05 \pm 1.45$ & $33.72 \pm 2.98$ & $8.50 \pm 1.68$ & $2.26 \pm 1.24$ & $14.79 \pm 2.48$ & $2.95 \pm 1.48$ \\
\hline
\end{tabular}

Dry weight of flower branch (g): There was a significant difference among (at $p<0.001)$ the applications regarding the fresh weight of flower branch so that $\mathrm{D}$ and $\mathrm{B}$ applications showed higher fresh weight of flower branch $(6.94 \mathrm{~g}$ and $6.15 \mathrm{~g})$. The lower fresh weight of flower branch was obtained from A application (2.77 g) (Table 5, Fig. 3).

\section{Corm quality characteristics}

Corm diameter $(\mathrm{mm})$ : Data in Table 5 revealed that different applications had significant effect on diameter of corm. The corm diameter was significantly higher in the $\mathrm{E}$ application $(36.88 \mathrm{~mm})$ as compared to the $\mathrm{F}$ application (31.41 mm). E application was increased in corm diameter with rate of $17.41 \%$ according to $\mathrm{F}$ application.

Corm length $(\mathrm{mm})$ : The results in Figure 2 showed that the applications did not significantly differ in terms of corm length.

Number of contractile root per corm: The maximum number of contractile root per corm was recorded in $\mathrm{D}$ application. It was found to be statistically at same group with applications, $\mathrm{C}$ and $\mathrm{E}$. The minimum number of contractile root per corm was obtained from the $\mathrm{F}$ application (6.75) (Table 5).

Number of corm and cormel: The A application produced the maximum number of corms and cormels (4.13 number/plant). The other applications were statistically similar (Table 5). E application was increased in number of corms and cormels with rate of $151.83 \%$ according to $\mathrm{F}$ application.

Corm fresh weight $(g)$ : The highest corm fresh weight was observed in the $\mathrm{C}$ application (17.66 g) which was significantly higher than that of the other applications. The lowest corm fresh weight was determined in $\mathrm{F}$ application (11.84 g) (Table 5).

Corm dry weight ( $g$ ): The highest corm dry weight and increasing rate of $129.72 \%$ was observed in the B application $(4.87 \mathrm{~g})$ which was significantly higher than the F applications (2.12 g) (Table 5).

\section{Discussion}

The results indicated that using autoclaved vermicompost as organic material and autoclaved vermicompost enriched with bacteria formulation increased the yield, quality of corms and flowers of Gladiolus grandiflorus L.. Our results are compatible with the findings of other researchers (Gangaharan and Gopinath, 2000; Atta-Alla et al., 2003; Khan et al., 2012; Singh et al., 2016; Tirkey et al., 2017; Akter et al., 2017). Growth and development of plants is due to the presence of humic acids (Albanell et al., 1988; Joshi et al., 2015) and micro and macronutrients in plantavailable forms (Orozco et al., 1996; Joshi et al. 2015) in vermicompost. The highest increase in plant height of gladiolus was observed when only PGPBs (A application; $75.50 \mathrm{~cm}$ ) were applied. This result is in accordance with the findings of studies (Zulueta-Rodriguez et al., 2014; Arab et al., 2015; Parlakova Karagöz et al., 2016) related to ornamental plants. Plant heights of $70.34 \mathrm{~cm}$ and 69.57 $\mathrm{cm}$ were recorded in treatments with $\mathrm{D}$ and $\mathrm{C}$, respectively. Mirakalaei et al. (2013) was reported that plant height of Lilium longiflorum was greater in vermicompost treatment as compared to control. Our finding of vermicompost $(\mathrm{C}$ application) to increase plant height of gladiolus is close in conformity with the findings of Asciutto et al. (2006) and Mirakalaei et al. (2013). Number of leaves was increased in $\mathrm{C}$ (Autoclaved vermicompost) application and ranged from 8.19 to 6.44 number/plant. These finding is close in with the result of Tirkey et al. (2017), who found that number of leaves of gladiolus (Gladiolus grandiflorus) cv. Jester ranged from 8.53 to 5.93 number/plant. According to findings of Chaudhary et al. (2013), number of gladiolus leaves were increased in vermicompost application. In addition, the highest increase in the number of gladiolus leaves in the present study was determined in $\mathrm{C}$ application (autoclaved vermicompost application).

Autoclaved vermicompost + PGPB have considerable potential for improving plant growth and corm quality 
significantly when used as a component in gladiolus cultivation. The beneficial effect of this application was evident since they increased gladiolus plant development; days of flowering; plant height, main stem diameter of plant, a* value of leaf, spike length, stalk length, corm diameter and number of corm and cormel per plant in comparison with the plants amended with the control and not autoclaved vermicompost application. Vermicompost is the combination of the earthworms and the microorganisms (Singh et al., 2011). Microorganism found in the intestine and gut of earthworms get its nourishment from organic material and decompose it into finer particles (Edwards and Bohlen, 1996). Vermicompost is in rich microbial agents and diversity, specifically bacteria, fungi and actinomycetes (Arancon et al., 2004). Vermicomposts also contain the pathogens due to the vermicomposting process temperature (35 ${ }^{\circ} \mathrm{C}$ (Ali et al., 2015)) is not high enough for pathogen kill (Ndegwa and Thompson, 2001). Ndegwa and Thompson (2001) considered that there can be two possibilities that are generally proposed to achieve better output by using vermicomposts: prevermicomposting followed by composting or precomposting followed by vermicomposting. Gajalakshmi et al. (2002) obtained that growth of water hyacinth was increased by using the precomposting followed by vermicomposting. The above findings are close in conformity with the findings of (Gajalakshmi et al., 2002).

\section{Conclusions}

The present investigation concluded that combining autoclaved vermicompost and PGPB can be used to increase the number and diameter of corm, which is one of the most important parameters for gladiolus used as production materials. Autoclaved vermicompost can be good choice in gladiolus cultivation but it should be enriched with PGPB. This results can be used to develop more efficient and environmentally friendly fertilizer management plans for commercial gladiolus corm production and landscape use. In addition, it may be recommended to use formulations of different PGPBs for further studies.

\section{Author Contribution}

F.P.K. ${ }^{0000-0001-7417-1716}$ : Installation of the experiment, analysis and collect of data, preparation of the manuscript. A.D. ${ }^{0000-0002-8475-}$ ${ }^{8534}$ : Installation of the experiment, conduction, preparation of the manuscript. N.T. ${ }^{0000-0003-2396-7786}$ : Collaboration in the preparation of manuscript in materials and methods. R.K. ${ }^{0000-0002-5836-6473}$ : Collaboration in the conducted of the experiment. R.K. ${ }^{0000-0001-}$ 6493- 8936: Creation idea, preparation of the manuscript, research orientation, suggestions and ideas

\section{References}

AKTER, N., ARA, K. A., AKAND, M. H., ALAM, M. $\mathrm{K}$. Vermicompost and trichocompost in combination with inorganic fertilizers increased growth, flowering and yield of Gladiolus cultivar (GL-031)(Gladiolus grandiflorus L.). Advances in Research, v.12, n.3, p.1-11, 2017.
ALBANELL, E., PLAIXATS, J., CABRERO, T. Chemical changes during vermicomposting (Eisenia fetida) of sheep manure mixed with cotton industrial wastes. Biology and fertility of soils, v.6, n.3, p.266-269, 1988.

ALI, U., SAJID, N., KHALID, A., RIAZ, L., RABBANI, M. M., SYED, J. H., MALIK, R. N. A review on vermicomposting of organic wastes. Environmental Progress \& Sustainable Energy, v.34, n.4, p.1050-1062, 2015.

ARAB, A., ZAMANI, G. R., SAYYARI, M. H., ASILI, J. Effects of chemical and biological fertilizers on morphophysiological traits of marigold (Calendula officinalis L.). European Journal of Medicinal Plants, v.8, n.1, p.60, 68, 2015.

ARANCON, N. C, EDWARDS, A., BIERMAN, P., WELCH, C., METZGER, J. D. Influences of vermin composts on field strawberries: 1. Effects on growth and yields. Bioresource Technology, v.93, p.145-153, 2004.

ASCIUTTO, K., RIVERA, M.C., WRIGHT, E.R., MORISIGUE, D., LÓPEZ, M.V. Effect of vermicompost on the growth and health of Impatiens wallerana. International Journal of Experimental Botany, v.75, p.115-123, 2006.

ATTA-ALlA, H. K., ZAGHLOUL, M. A., BARKA, M., HASHISH, K. H. Effect of organic manure and NPK fertilizers on the vegetative growth, flowering and chemical composition of some gladiolus cultivars. Annals of Agricultural Science, Moshtohor, v.41, n.2, p.889-912, 2003.

BACHMAN, G. R., METZGER, J. D. Growth of bedding plants in commercial potting substrate amended with vermicompost. Bioresource technology, v.99, n.8, p.31553161, 2008.

BALAJI, S., KULKARNI, M., REDDY, B.S., PATIL, B.C., DIVAKARA, A. Influence of vermicompost and in situ vermiculture on the quality attributes and saleable yield in China aster. Scientific Horticulture, v.10, p.217221, 2006.

BAWA, U., BUKAR, A., ABDULLAHI, Y., SAMUEL, A. The role of earthworms in soil structure, nutrients cycle and vermicomposting. ATBU Journal of Science, Technology and Education, v.4, n.2, p.149-156, 2016.

CHAUDHARY, N., SWAROOP, K., JANAKIRAM, T., BISWAS, D. R., SINGH, G. Effect of integrated nutrient management on vegetative growth and flowering characters of gladiolus. Indian Journal of Horticulture, v.70, n.1, p.156-159, 2013. 
CRUZ, L. R. D. D., LUDWIG, F., STEFFEN, G. P. K., MALDANER, J. Development and quality of gladiolus stems with the use of vermicompost and Trichoderma sp. in substrate. Ornamental Horticulture, v.24, n.1, p.70-77, 2018.

EDWARDS, C.A., BOHLEN, P.J. Biology and ecology of earthworms, London: Chapman and Hall, 1996.

GAJALAKSHMI, S., RAMASAMY, E., ABBASI, S. Vermicomposting of paper waste with the anecic earthworm Lampito mauritii Kinberg. Indian Journal of Chemical Technology v.9, p.306-311, 2002.

GANGADHARAN, G. D., GOPINATH, G. Effect of organic and inorganic fertilizers on growth, flowering and quality of Gladiolus cv. white prosperity. Karnataka Journal of Agricultural Sciences v.11, n.3, p.401-405, 2000 .

HIDALGO, P. R. HARKESS, R. L. Earthworm castings as a substrate amendment for chrysanthemum production. Hortscience, v.37, n.7, p.1035-1039, 2002.

HIDAlgO, P. R., MATTA, F. B., HARKESS, R. L. Physical and chemical properties of substrates containing earthworm castings and effects on marigold growth. HortScience, v.41, n.6, p.1474-1476, 2006.

JABBAR, A., TAHRANIFAR, A.,SHUOR, M., NEMATI, S.H. Effect of different media on some growth, flowering and biochemical parameters of two cultivars of gladiolus (Gladiolus grandifloras L.) under soilless conditions. Journal of Ornamental Plants, v.8, n.3, p. 205-215, 2018. DOI: http://jornamental.iaurasht.ac.ir/article_542591.html

JOSHI, R., SINGH, J., VIG, A. P. Vermicompost as an effective organic fertilizer and biocontrol agent: effect on growth, yield and quality of plants. Reviews in Environmental Science and Bio/Technology, v.14, n.1, p.137-159, 2015.

KARUPPAIAH, P. Effect of Azospirillum, phosphobacteria and organic manures on growth and yield of French marigold (Tagetes patula L.). Plant Archives, v.5, n.2, p.661-664, 2005.

KHAN, F. N., RAHMAN, M. M., KARIM, A. J. M. S., HOSSAIN, K. M. Effects of nitrogen and potassium on growth and yield of gladiolus corms. Bangladesh Journal of Agricultural Research, v.37, n.4, p.607-616, 2012.

KOTAN. R., SAHIN, F., ALA, A. Identification and pathogenicity of bacteria isolated from pome fruits trees in eastern Anatolia region of Turkey. Journal of Plant Diseases and Protection, v.113, n.1, p.8-13, 2005.
Mirakalaei, S. M. M., Ardebill, Z. O., Mostafavi, M. The effects of different organic fertilizers on the growth of lilies (Lillium longiflorum). International Research Journal of Applied and Basic Sciences, v.4, n.1, p.181-186, 2013.

NARAYANAGOWDA, J. V. Effect of vermicompost and biofertilizers on growth and yield of gerbera (Gerbera jamesonii L.) cv. Local. National Symposium on Recent Advances in Indian Floriculture, Vellanikara, India, Kerala Agricultural University, p. 19, 2003.

Nazari, F., Farahmand, H., Eshghi, S., Niki, M., Eslamzade, M. The effect of different soil amendments on growth and flowering of African marigold (Tagetes erecta L.) 'Queen'. Journal of Fruit and Ornamental Plant Research, v.16, p.403-415, 2008.

NDEGWA, P., THOMPSON, S. Integrating composting and vermicomposting in the treatment and bioconversion of biosolids. Bioresource Technology, v.76, p.107- 112, 2001.

NETHRA, N. N., JAYAPRASAD, K. V., RADHA, D. K. China Aster (Callistephus chinensis (L.) Nees) cultivation using vermicompost as organic amendment. Crop Research, Hisar, v.17, n.2, p.209-215, 1999.

PANDEY, S. K., KUMARI, S., SINGH, D., SINGH, V. K., PRASAD, V. M. Effect of biofertilizers and organic manures on plant growth, flowering and tuber production of dahlia (Dahlia variabilis L.) Cv. SP Kamala. International Journal of Pure \& Applied Bioscience, v.5, n.2, p.549$555,2017$.

PARLAKOVA KARAGÖZ, F., DURSUN, A., KOTAN, R., EKINCI, M., YILDIRIM E., MOHAMMADI, P. Assessment of the effects of some bacterial isolates and hormones on corm formation and some plant properties in saffron (Crocus sativus L.). Ankara University Journal of Agricultural Sciences, v.22, n.4, p.500-511, 2016.

RIVERM, Vermicompost, Rivo's Ranch. https://riverm. com.tr/tr/urunler-rivo-kati-solucan-gubresi.asp., 2018. Accessed 26 December 2018.

SENG, S., WU, J., SUI, J., WU, C., ZHONG, X., LIU, C., LIU, C., GONG B., ZHANG F., HE J., YI, M. ADP-glucose pyrophosphorylase gene plays a key role in the quality of corm and yield of cormels in gladiolus. Biochemical and Biophysical Research Communications, v.474, n.1, p.206-212, 2016.

SHADANPOUR, F., TORKASHVAND, A. M., MAJD, K. $H$. The effect of cow manure vermicompost as the planting medium on the growth of Marigold. Annuals of Biological Research, v.2, n.6, p.109-115, 2011. 
SHWETA SINGH, Y. P. Effect of vermicomposting on the growth and productivity of marigold (Tagetes erecta L.) an important medicinal and ornamental herb. (Recent Progress in Medicinal Plants). Phytomedicines, v.16, p.615-621, 2007.

SINGH, R., EMBRANDIRI, A., IBRAHIM, M., ESA, N. Management of biomass residues generated from palm oil mill: Vermicomposting a sustainable option, Resources. Conservation and Recycling, v.55, p.423-434, 2011.

SINGH, S., SINGH, J., VIG, A. P. Earthworm as ecological engineers to change the physico-chemical properties of soil: soil vs vermicast. Ecological Engineering, v.90, p.1$5,2016$.

TIRKEY, P., KULlUR, L. R., PRASAD, V. M. Effect of organic and Inorganic source of NPK on growth and yield parameters of gladiolus (Gladiolus grandiflorus) cv. Jester. Journal of Pharmacognosy and Phytochemistry, v.6, n.5, 1004-1006, 2017.
WARADE, A. P.; GOLLIWAR, V. J.; CHOPDE, N.; LANJE, P. W., THAKRE, S. A. Effect of organic manures and bio-fertilizers on growth, flowering and yield of Dahlia. Journal of Soils \& Crops, v.17, n.2, p.354-357, 2007.

YANG, L., ZHAO, F., CHANG, Q., LI, T., LI, F. Effects of vermicomposts on tomato yield and quality and soil fertility in greenhouse under different soil water regimes. Agricultural Water Management, v.160 p.98$105,2015$.

ZULUETA-RODRIGUEZ， R., CORDOBA-MATSON M.V., HERNANDEZ-MONTIEL L.G., MURILLOAMADOR B., RUEDA-PUENTE E., LARA L. Effect of Pseudomonas putida on growth and anthocyanin pigment in two poinsettia (Euphorbia pulcherrima) cultivars. The Scientific World Journal, Article ID : 810192, 6 pages, 2014. 